\title{
Hubungan Asupan Vitamin D Dan Selenium Dengan Indeks Bakteriologi Penderita Kusta Tipe MB (Multibacillary) : Systematic Literature Review
}

\section{Relationship Of Vitamin D and Selenium Intake with Bacteriological Index of Type of Christian Push Type MB (Multibacillary) : Systematic Literature Review}

\author{
Fildzah Karunia Putri ${ }^{1 *}$, Eka Zulfiana Yusyifak ${ }^{2}$, Rizki Nurmalya Kardina ${ }^{3}$ \\ 1,2,3 Program Studi S1 Gizi Fakultas Kesehatan Universitas Nahdlatul Ulama Surabaya \\ Jalan Smea No.57, Wonokromo, Kota Surabaya, Jawa Timur, Indonesia \\ *Corresponding author \\ Email: fildzahkarunia@unusa.ac.id
}

\begin{abstract}
Keyword :
Leprosy,

Vitamin D,

Selenium,

Bacteriological

Index

A b stract

Background : As one of the infectious diseases that have a high prevalence until now, leprosy is a chronic transmission disease caused by infection with Mycobacterium Leprae. Apart from the standard MDT (Multidrug Therapy), nutritional support is a crucial component to restrict further infection severity. Vitamin D and selenium play essential roles as the primary defence against susceptibility. Methods : The systematic literature review was conducted using three international databases: PubMed, ResearchGate, and DOAJ, which were published between 2010 - 2020 using English or Indonesian. A total of 8 articles $(2$ articles identifying the correlation of selenium with leprosy, and 6 articles identifying the correlation of vitamin D with leprosy) using cross- sectional analytic and case-control analytic studies were included in this review. Results : The average serum levels of vitamin D and selenium in leprosy patients were lower than in healthy controls. This case was also found in Multibacillary leprosy patients compared to Paucibacillary leprosy patients. This serum levels can affect the bacteriological index, which is the higher the serum levels, the lower the bacteriological index. Disscusion : Serum vitamin D and selenium levels are affected by vitamin $D$ and selenium intake, which can lead to a reduction in bacteriological index across all multibacillary leprosy patients. There is a negative correlation between vitamin $D$, selenium, and bacteriological index in patients with MB (Multibacillary) leprosy.
\end{abstract}

\section{Kata kunci :}

Kusta,

Vitamin D,

Selenium,

Indeks

Bakteriologis

\begin{abstract}
A B S T R A K
Latar belakang : Salah satu penyakit kulit menular yang hingga saat ini masih memiliki prevalensi tinggi adalah kusta atau lepra, yakni penyakit menular kronik yang disebabkan karena infeksi bakteri Mycobacterium leprae. Selain pengobatan rutin MDT (Multidrug Therapy), perlu adanya dukungan nutrisi sebagai upaya pencegahan terhadap keparahan infeksi lebih lanjut. Vitamin D dan selenium berperan penting sebagai pertahanan utama tubuh terhadap kerentanan infeksi. Metode : Penelitian ini menggunakan metode Systematic Literature Review dengan tujuan mengidentifikasi hubungan asupan vitamin D dan selenium dengan indeks bakteriologi pada penderita kusta tipe MB (Multibacillary). Studi ini mengacu pada hasil pencarian dari 3 international database : PubMed, ResearchGate, dan DOAJ, yang dipublikasikan antara 2010 - 2020 menggunakan bahasa Inggris atau bahasa Indonesia. Sebanyak 8 artikel (2 artikel mengidentifikasi hubungan selenium dengan kusta, dan 6 artikel mengidentifikasi hubungan vitamin D dengan kusta) dimasukkan dalam review ini dengan jenis penelitian analitik cross sectional dan analitik case control. Hasil : Rata-rata level serum vitamin D dan selenium pada penderita kusta lebih rendah dibandingkan dengan kontrol sehat. Kasus ini juga ditemukan pada penderita kusta MB (Multibacillary) dibandingkan penderita kusta tipe PB (Paucibacillary). Level serum ini dapat berpengaruh pada indeks bakteriologi. Kesimpulan : Asupan vitamin D dan selenium yang adekuat dapat mempengaruhi level serum vitamin D dan selenium
\end{abstract}


sehingga nilai indeks bakteriologi dapat berkurang atau menurun. Terdapat korelasi negatif antara vitamin D, selenium, dan indeks bakteriologi pada penderita kusta MB (Multibacillary).

How To Cite : Putri, F.K.,Yusyifak, E.Z.,\&Kardina R.M. 2021.Hubungan Asupan Vitamin D dan Selenium Dengan Indeks Bakteriologi Penderita Kusta Tipe MB (Multibacillary): Systematic Literature Review. Journal of Islamic Medicine.5(2),83-95.

https://doi.org/10.18860/jim.v5i2.12974

Copyright $\left({ }^{\circ} 2021\right.$

\section{LATAR BELAKANG}

Daerah tropis dan subtropis seperti benua Asia, sebagian benua Australia, Amerika Tengah dan Selatan, serta Afrika merupakan daerah yang lazim terjadi penyakit infeksi menular. Indonesia menjadi salah satu negara di Asia yang masih mengalami masalah kesehatan terkait penyakit infeksi menular. ${ }^{1}$ Salah satu penyakit kulit menular yang hingga saat ini masih memiliki prevalensi tinggi di Indonesia adalah kusta atau lepra. Penyakit kusta merupakan penyakit menular kronik yang disebabkan karena infeksi bakteri Mycobacterium Leprae yang menginfeksi makrofag kulit dan sel Schwann di saraf perifer. $^{2,3}$

Berdasarkan WHO (1981) terdapat 2 klasifikasi kusta yakni tipe PB (Paucibacillary) dan tipe MB (Multibacillary). ${ }^{4}$ Perbedaan antara PB dan MB terletak pada nilai positif dari pemeriksaan Slit Skin Smear, dimana pasien dengan indeks bakteriologi lebih dari 2 termasuk MB dan jika indeks bakteriologi kurang dari 2 termasuk PB. Jika yang terlibat hanya 1 syaraf maka termasuk kusta PB, tetapi jika yang terlibat banyak syaraf maka diberi label MB (WHO, 2000). ${ }^{4}$

Pada tahun 2015 Asia Tenggara menjadi penyumbang terbesar kasus kusta terbaru yakni sejumlah 156.118 kasus. Selama rentang tahun 2006 - 2015 tercatat sebanyak 14 negara yang melaporkan 1000 atau lebih kasus kusta baru, dimana Indonesia menempati urutan tertinggi ketiga setelah India dan Brazil. $^{5}$ Di Indonesia terdapat 85,46\% dari 17.017 kasus baru kusta yang merupakan kusta tipe MB. ${ }^{6}$ Hal tersebut yang mendasari peneliti untuk menganalisis lebih jauh mengenai kusta tipe MB.
Sistem kekebalan bawaan merupakan pertahanan utama tubuh dalam melawan infeksi secara cepat. Kekurangan gizi berkaitan dengan faktor lingkungan maupun genetik inang menjadi salah satu penyebab klinis kusta. ${ }^{7}$ Vitamin D sebagai regulator imunitas bawaan pada penyakit TBC dan kusta. ${ }^{8}$ Mekanisme vitamin D pada kusta adalah mempengaruhi kemampuan makrofag dalam membunuh patogen dengan cara meningkatkan ekspresi antimikroba peptida katelisidin. ${ }^{7,9}$ Pada sebuah penelitian dijumpai bahwa semakin rendah tingkat plasma vitamin D reseptor (VDR), maka indeks bakteriologi pada pasien kusta akan semakin tinggi. ${ }^{9}$

Selain itu disfungsi kekebalan tubuh juga dihubungkan dengan defisiensi mineral selenium yang dapat meningkatkan patogenesis dan keparahan infeksi. ${ }^{10}$ Selenium bekerja dengan cara aktivasi glutation peroksidase yang mengkatalisis reduksi hydrogen peroksidase dan hidroperoksida organik dan melindungi lemak dari kerusakan oksidatif. ${ }^{7,11}$ Sebuah penelitian menyebutkan bahwa kadar selenium pada pasien kusta PB lebih tinggi daripada pasien kusta $\mathrm{MB}$, dengan catatan jika indeks bakteriologi yang semakin tinggi maka kadar serum selenium akan semakin rendah. ${ }^{11}$

Pada tahun 1982, WHO merekomendasikan bahwa seluruh pasien kusta harus diobati dengan kombinasi dari 2 atau 3 obat (Rifampin, Dapsone, dan Clofazimine) yang disebut MDT (Multidrug Therapy) untuk mencegah terjadinya resistensi $M$. leprae terhadap obat anti-kusta tunggal yang diberikan. Menurut latar belakang yang ada, studi penelitian systematic review ini bertujuan untuk mengidentifikasi hubungan antara asupan 
vitamin $\mathrm{D}$ dan selenium dengan indeks bakteriologi pada pasien kusta tipe MB (Multibacillary), sebab kusta merupakan penyakit menular multifaktoral yang dipengaruhi oleh genetik dan lingkungan sehingga berefek pada kerentanan terhadap infeksi dan tingkat pengaruh nutrisi dari vitamin D dan selenium.

\section{METODE}

Studi penelitian ini menggunakan metode Systematic Literature Review (SLR), dimana penelitian dilakukan dengan cara mengidentifikasi atau mengevaluasi secara sistematis terhadap semua hasil penelitian yang relevan terkait pertanyaan penelitian dan topik penelitian tertentu. Penggunaan metode ini disebabkan karena adanya pandemi Corona Virus Disease 2019 (COVID-19), yang sedang terjadi di seluruh dunia termasuk Indonesia. Penulisan SLR ini berdasarkan pedoman Preferred Reporting Items for Systematic Reviews and MetaAnalyses (PRISMA) sebagai protokol peninjauan dan pemilihan studi. Studi literatur ini meninjau sebanyak 8 artikel (4 artikel menggunakan metode analitik cross sectional dan 4 artikel menggunakan metode analitik case control).

Kriteria inklusi pada studi literatur mengacu pada pedoman PICOS (Participants, Interventions, Comparisons, Outcomes and Study Design). Beberapa kriteria inklusi pada studi ini antara lain: 1) Pasien merupakan penderita kusta tipe MB dalam masa pengobatan MDT; 2) Sampel yang diteliti adalah vitamin $\mathrm{D}$ dan selenium; 3) Luaran hasil studi adalah asupan vitamin $\mathrm{D}$, asupan selenium, level serum vitamin $\mathrm{D}$, level serum selenium, dan indeks bakteriologi; 4) Study design yang digunakan adalah analitik cross sectional, analitik case control, dan RCT (Randomized Controlled Trial).

Sedangkan untuk kriteria eksklusi pada studi literatur ini antara lain : 1) Studi penelitian pada pasien kusta tipe PB baik dalam masa pengobatan MDT maupun masa pengamatan / Released From Treatment
(RFT); 2) Studi penelitian dalam bentuk suntingan, abstrak tanpa artikel teks lengkap, dan penelitian yang tidak memiliki informasi cukup terkait metode analisis; 3) Studi penelitian dengan tahun terbit lebih dari 10 tahun; 4) Studi penelitian yang menggunakan selain bahasa Indonesia dan bahasa Inggris; 5) Studi artikel dalam bentuk review text dan report case.

Studi literatur ini mengacu pencarian studi pada 3 jenis database, yaitu PubMed, ResearchGate, dan DOAJ dengan rentang waktu maksimal 10 tahun terakhir. Strategi pencarian pada studi literatur ini menggunakan beberapa kata kunci yang berbeda tiap database. Peneliti menggunakan kata kunci terkait sampel penelitian dan luaran hasil penelitian, serta agar pencarian menjadi lebih luas peneliti menggunakan kata bantu And pada tiap kata kunci. Berikut kata kunci yang digunakan pada masingmasing database :

1)PubMed: "leprosy" AND "vitamin D" dan "leprosy" AND "selenium"; 2)ResearchGate: "leprosy" AND "vitamin D" dan "leprosy" AND "selenium"; 3)DOAJ : "leprosy" AND "bacterial index", "leprosy" AND "micronutrient", "vitamin D" AND "mycobacterium leprae". Hasil pencarian studi dari 3 basis data elektronik di atas sebanyak 213 artikel penelitian (PubMed: 76; ResearchGate: 93; DOAJ: 44), kemudian dilakukan analisis studi penelitian berdasarkan kriteria inklusi dan eksklusi yang telah ditetapkan sebelumnya (Gambar $1)$.

Proses seleksi pada studi literatur ini melalui 4 tahap, antara lain: 1) Proses identifikasi, yakni studi dianalisis dari 3 database (PubMed, ResearchGate, dan DOAJ) yang mendapatkan sejumlah 213 artikel; 2) Proses penyaringan/screening, pada proses ini artikel yang duplikat sebanyak 28 disisihkan sehingga sisa 185 artikel. Kemudian ditinjau melalui judul, abstrak, dan kata kunci mendapatkan hasil sebanyak 168 artikel dikeluarkan dengan 7 kriteria (study design/method, study participant, no abstract, review/report text, language, study outcome, >10 years) yang 
tidak memenuhi kriteria inklusi. Tahap penyaringan selanjutnya, sebanyak 17 artikel yang memenuhi kriteria inklusi ditinjau ulang namun secara fulltext, mendapatkan hasil sebanyak 9 artikel yang dikeluarkan dengan 5 kriteria (study design/method, review text, language, study outcome, no complete information) yang tidak memenuhi kriteria inklusi; 3) Tahap ketiga proses penentuan kelayakan studi literatur, yakni sebanyak 8 artikel dilakukan penilaian kualitas studi menggunakan JBI Critical Appraisal tools, yakni berupa 8 pertanyaan (jenis penelitian analitik cross sectional) dan 10 pertanyaan (jenis penelitian analitik case control) terkait isi dari 8 artikel penelitian tersebut; 4) Tahap terakhir, sebanyak 8 studi literatur yang telah dipilih kemudian diekstrasi menggunakan kriteria inklusi dan eksklusi berdasarkan pedoman PICOS untuk disajikan dalam tabel dan dianalisis secara deskriptif.

\section{HASIL PENELITIAN}

\section{A. Hasil Pencarian}

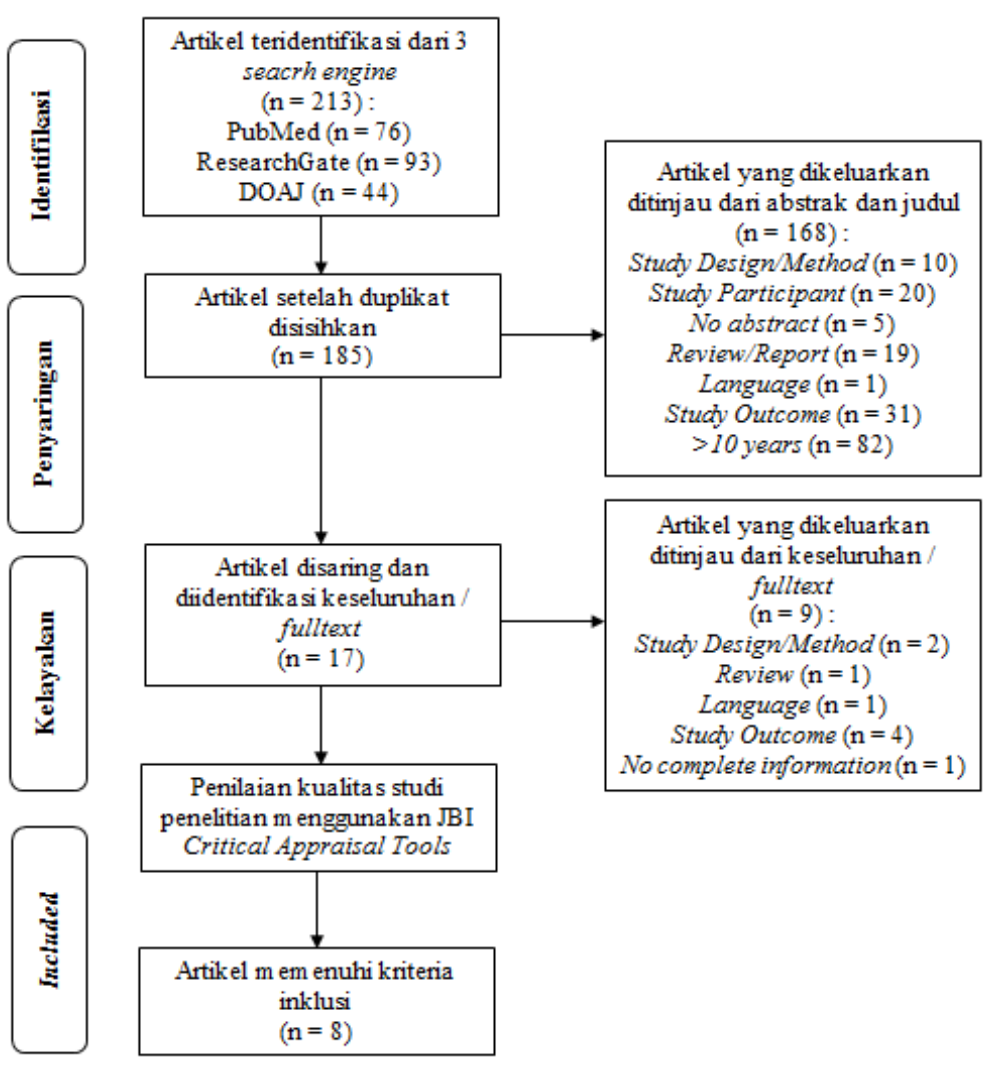

Gambar 1. Diagram PRISMA, Alur Proses Analisis Studi Artikel

Gambar 1. di atas menyajikan diagram alur pencarian studi secara sistematis. Tahap pertama proses identifikasi, yakni identifikasi dari 3 database (PubMed, ResearchGate, dan DOAJ) yang mendapatkan sejumlah 213 artikel. Kemudian proses penyaringan / screening, artikel duplikat sebanyak 28 disisihkan dan tersisa 185 artikel. Lalu ditinjau melalui judul, abstrak, dan kata kunci, sebanyak 168 artikel dikeluarkan karena tidak memenuhi kriteria inklusi. Tahap screening selanjutnya sebanyak 17 artikel yang memenuhi kriteria inklusi ditinjau secara fulltext dan mendapatkan hasil sebanyak 9 artikel yang dikeluarkan karena tidak memenuhi kriteria inklusi. Pada tahap ketiga terdapat proses penentuan kelayakan studi literatur, yakni sebanyak 8 artikel dilakukan penilaian kualitas studi menggunakan JBI Critical Appraisal tools, 
dan tahap terakhir sebanyak 8 studi literatur yang telah dinilai kemudian diekstrasi menggunakan kriteria inklusi dan eksklusi berdasarkan pedoman PICOS untuk disajikan dalam tabel dan dianalisis secara deskriptif.

\section{B. Karakteristik Studi Systematic Literature Review}

Hasil pencarian studi literatur terkait hubungan asupan vitamin $\mathrm{D}$ dan selenium dengan indeks bakteriologi pada penderita kusta tipe MB melalui basis data elektronik (systematic literature review) mendapat 8 artikel penelitian yang terpilih. Secara keseluruhan penelitian pada studi literatur ini menggunakan metode analitik cross sectional dan case control, dimana terdapat 4 artikel pada masing-masing metode. Populasi pada studi penelitian terpilih adalah pasien kusta tipe PB dan MB dengan usia beragam. Secara keseluruhan lokasi penelitian terdapat di tiga negara, yakni 4 artikel penelitian di Indonesia, 2 artikel penelitian di India, dan 2 artikel penelitian di Brazil. Sampel yang diteliti adalah polimorfisme gen VDR, level serum vitamin A, B, C, D, dan E, level serum selenium, kadar cathelicidin peptide, indeks bakteriologi, demografi, sosial ekonomi, diet dan nutrisi, BMI, keragaman makanan, dan profil asupan zat besi (Tabel 1).

\section{Hasil Penelitian Studi Systematic Literature Review}

Hasil analisis studi literatur dari 8 artikel, menunjukkan bahwa asupan vitamin D sangat penting bagi pasien penderita kusta sebagai anti mikroba. Pengaruh haplotipe yang dibentuk oleh gen VDR polimorfisme dapat memberikan perlindungan terhadap kusta $(\mathrm{p}=0,004, \quad \mathrm{OR}=0,34, \quad \mathrm{CI}=0,16-0,71$; $\mathrm{p}=0,005, \quad \mathrm{OR}=0,30, \quad \mathrm{CI}=0,13-0,70) \quad$ [12]. Beberapa artikel menjelaskan bahwa defisiensi vitamin D dapat menjadi faktor penyebab berkembangnya penyakit kusta dan bahkan dapat menjadi faktor resiko yang lebih tinggi pada individu yang mengalami defisiensi vitamin D sekaligus merupakan kontak erat pasien penderita kusta tipe MB. ${ }^{9}$

Secara umum 8 artikel penelitian menjelaskan bahwa rata-rata level serum vitamin D (VDR) pada pasien penderita kusta lebih rendah dibandingkan individu yang sehat. Hal ini dapat dipengaruhi oleh beberapa faktor, seperti tingkat pengetahuan, faktor sosial ekonomi, dan yang utama adalah faktor asupan nutrisi $(p=0,000)$ [13]. Secara signifikan level serum vitamin $\mathrm{D}$ pada pasien penderita kusta MB lebih rendah dibandingkan dengan pasien penderita kusta $\mathrm{PB}$, dimana kondisi tersebut berhubungan dengan indeks bakteriologi pasien penderita kusta MB yang lebih tinggi dibandingkan pada pasien penderita kusta PB $(\mathrm{p}<0,05) .{ }^{14}$ Sehingga dapat dikatakan bahwa level serum vitamin $\mathrm{D}$ berkorelasi kuat dengan indeks bakteriologi pada pasien penderita kusta MB $(\mathrm{r}=-0,954 ; \mathrm{p}<0,001){ }^{9}$ Sedangkan untuk level serum selenium pada pasien penderita kusta MB secara signifikan menunjukkan angka yang lebih rendah dibandingkan pada pasien kusta PB, sehingga kondisi tersebut juga menunjukkan korelasi yang kuat antara level serum selenium dengan indeks bakteriologi $(r=-0,499 ; p=0,005){ }^{11}$

\section{PEMBAHASAN}

\section{A. Mekanisme Vitamin D terhadap Indeks Bakteriologi}

Vitamin D berperan penting dalam respon imun, yakni mempengaruhi respon imun bawaan dan respon imun adaptif. Pada respon imun bawaan, vitamin D menginduksi efisiensi diferensiasi monosit menjadi makrofag. ${ }^{15}$ Salah satu jalur aktivasi makrofag melibatkan peran vitamin $\mathrm{D}$ dan reseptornya (VDR). Makrofag menghasilkan 1,25(OH)2D3 dan VDR diekspresikan oleh berbagai sel imun seperti CD4+, CD8+, sel T, sel B, neutrofil, Antigen Presenting Cell (APC), dan dendritik. Pada penyakit kusta, vitamin D melalui interaksinya dengan VDR dapat mempengaruhi kemampuan makrofag dalam membunuh pathogen yakni meningkatkan ekspresi antimikroba cathelicidin peptide. Peningkatan pembunuhan pathogen / bakteri menandakan bahwa nilai indeks bakteriologi dapat berkurang / menurun. ${ }^{9}$ 
Tabel 1. Kriteria Hasil Pencarian Studi Literatur

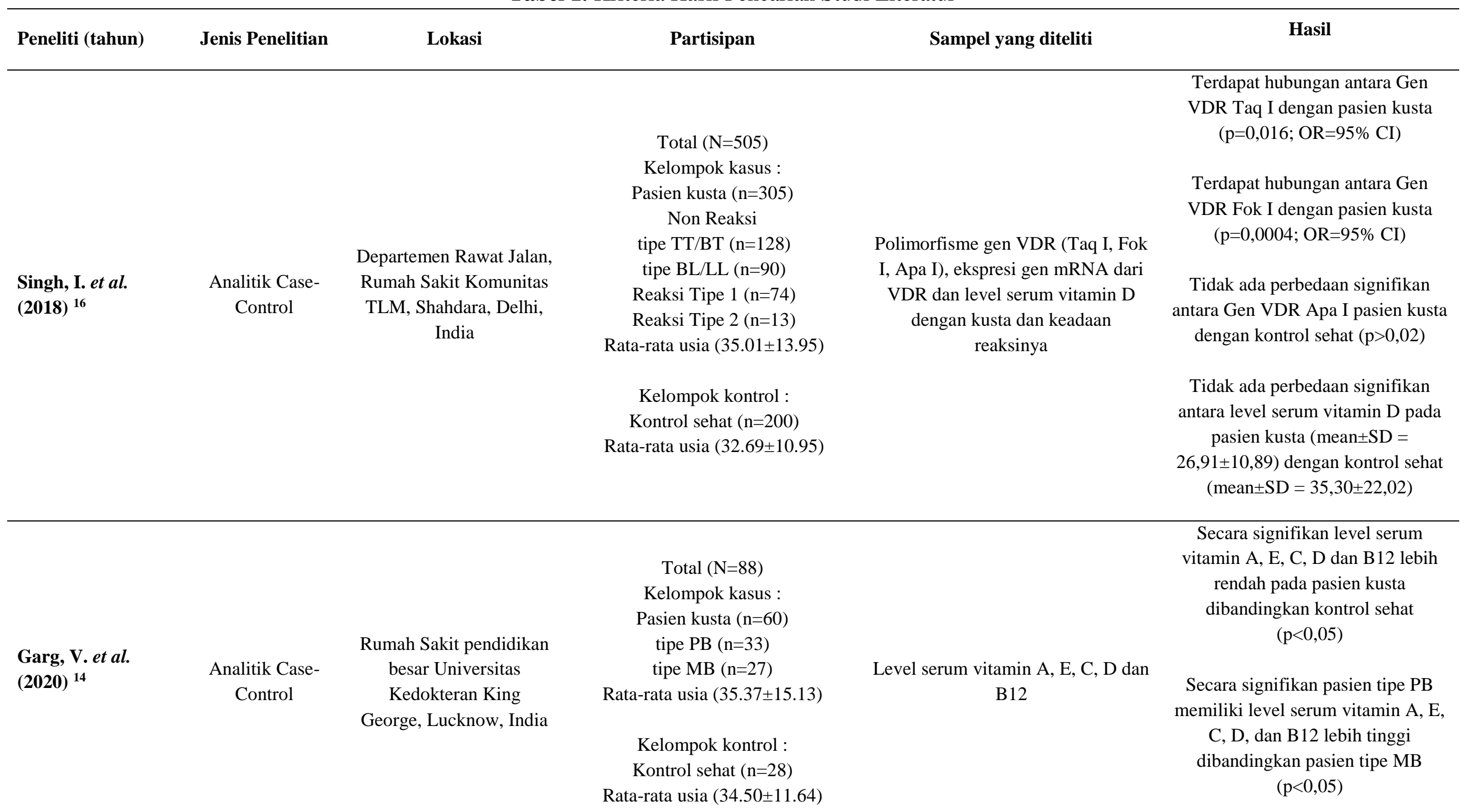




$\begin{array}{lcc}\text { Rusyati, L. M. } \text { et } & \text { Analitik Cross } & \begin{array}{c}\text { Poli Dermatologi Sub- } \\ \text { bagian Morbus Hansen }\end{array} \\ \text { al. (2019) } & \text { Sectional } & \text { RSU Sanglah, Bali }\end{array}$

\begin{tabular}{|c|c|}
\hline $\begin{array}{l}\text { Pepineli, A. C. et } \\
\text { al. (2019) } 12\end{array}$ & $\begin{array}{c}\text { Analitik Cross } \\
\text { Sectional }\end{array}$ \\
\hline
\end{tabular}

Total $(\mathrm{N}=47)$

Pasien kusta tipe MB ( $\mathrm{n}=47)$

Rentang usia

(5-75 tahun)

Terdapat hubungan secara

Level serum VDR dan indeks bakteriologi signifikan antara level plasma VDR dan indeks bakteriologi $(\mathrm{r}=-0,954 ; \mathrm{p}<0,001)$

Total $(\mathrm{N}=836)$

Kelompok kasus :

Pasien kusta $(n=404)$

tipe $P B(n=86)$

tipe MB (n=310)

tidak terklasifikasi $(\mathrm{n}=8)$

Rentang usia

(10-93 tahun)
Polimorfisme gen VDR (Bsm I, Apa I, Taq I, dan Fok I)

Terdapat hubungan antara pengaruh haplotipe yang dibentuk oleh gen

VDR polimorfisme dengan

perlindungan terhadap kusta dan

bentuk klinis MB ( $\mathrm{p}=0,004$,

$\mathrm{OR}=0,34, \mathrm{CI}=0,16-0,71 ; \mathrm{p}=0,005$, $\mathrm{OR}=0,30, \mathrm{CI}=0,13-0,70$ )

Kelompok kontrol :

Kontrol sehat $(\mathrm{n}=432)$

Rentang usia

(16-105 tahun)

Total $(\mathrm{N}=50)$

Kelompok kasus :

Pasien kusta tipe MB ( $\mathrm{n}=25)$

Rusyati, L. M. M. Analitik Case- Departemen Dermatologi et al. $(\mathbf{2 0 1 8})^{15} \quad$ Control dan Venerologi RSU Sanglah, Bali
Kelompok kontrol : Pasien kusta tipe PB (=25)

Rentang usia keseluruhan (6-65 tahun)
Secara signifikan kelompok (tipe

PB) memiliki level serum vitamin

D lebih tinggi dibandingkan dengan kelompok kasus (tipe MB) $(\mathrm{p}<0,05)$

Level serum vitamin D

Pasien dengan level serum vitamin D rendah memiliki faktor risiko yang lebih tinggi untuk tertular kusta $(\mathrm{OR}=12,667, \mathrm{CI}=95 \%)$

Terdapat hubungan secara

signifikan antara kadar serum

Pasien kusta $(\mathrm{n}=30)$

tipe PB $(n=19)$

tipe $\mathrm{MB}(\mathrm{n}=11)$

Rentang usia keseluruhan

(16-75 tahun)
Level serum selenium dan indeks bakteriologi selenium dengan indeks

bakteriologi pasien kusta

$(\mathrm{r}=-0,499 ; \mathrm{p}=0,005)$

(2018) ${ }^{11}$ Indonesia 


\begin{tabular}{|c|c|c|c|c|c|}
\hline $\begin{array}{l}\text { Oktaria, S. et } \\
\text { al.(2018) } 13\end{array}$ & $\begin{array}{l}\text { Analitik Case- } \\
\text { Control }\end{array}$ & $\begin{array}{c}\text { Daerah pedesaan } \\
\text { Bangkalan, Madura, } \\
\text { Jawa Timur, Indonesia }\end{array}$ & $\begin{array}{c}\text { Total }(\mathrm{N}=300) \\
\text { Kelompok kasus : } \\
\text { Pasien kusta }(\mathrm{n}=100) \\
\text { tipe PB }(\mathrm{n}=11) \\
\text { tipe MB }(\mathrm{n}=89) \\
\text { Kelompok kontrol : } \\
\text { Kontrol sehat }(\mathrm{n}=200) \\
\text { Rentang usia keseluruhan } \\
(16-65 \text { tahun) }\end{array}$ & $\begin{array}{l}\text { Demografi, sosial ekonomi, diet } \\
\text { dan nutrisi, BMI, keragaman } \\
\text { makanan, profil asupan zat besi }\end{array}$ & $\begin{array}{c}\text { Skor HFIAS (Household Food } \\
\text { Insecurity Access Scale) dua kali } \\
\text { lebih tinggi pada kelompok kasus } \\
\text { dibandingkan kelompok kontrol } \\
(\mathrm{p}=0,000)\end{array}$ \\
\hline $\begin{array}{l}\text { Oliveira, A. L. G. } \\
\text { de et al. } \\
(2020)^{20}\end{array}$ & $\begin{array}{l}\text { Analitik Case- } \\
\text { Control }\end{array}$ & $\begin{array}{c}\text { Pusat Rujukan Regional } \\
\text { untuk Penyakit Menular } \\
\text { di Belo Horizonte, } \\
\text { Ibukota Negara Bagian } \\
\text { Minas Gerais, Brazil }\end{array}$ & $\begin{array}{c}\text { Total }(\mathrm{N}=77) \\
\text { Kelompok kasus : } \\
\text { Pasien kusta }(\mathrm{n}=34) \\
\text { tipe } \mathrm{PB}(\mathrm{n}=14) \\
\text { tipe MB }(\mathrm{n}=20) \\
\text { Kontak rumah tangga }(\mathrm{n}=25) \\
\text { Kelompok kontrol : } \\
\text { Kontrol sehat }(\mathrm{n}=18) \\
\text { Rentang usia keseluruhan } \\
(18-60 \text { tahun })\end{array}$ & $\begin{array}{l}\text { Level serum vitamin D dan } \\
\text { cathelicidin peptide }\end{array}$ & $\begin{array}{l}\text { Terdapat hubungan secara } \\
\text { signifikan antara defisiensi vitamin } \\
\mathrm{D} \text { dengan kadar cathelicidin yang } \\
\text { rendah pada pasien yang tidak } \\
\text { berobat }(\mathrm{r}=0,86 ; \mathrm{p}=0,0003) \text { dan } \\
\text { pasien yang berobat }(\mathrm{r}=0,79 ; \\
\mathrm{p}=0,002)\end{array}$ \\
\hline
\end{tabular}


Tabel 2. Resiko Bias Studi Artikel menggunakan JBI Critical Appraisal Tools for Analytical Cross Sectional Studies

\begin{tabular}{|c|c|c|c|c|c|c|c|c|}
\hline & 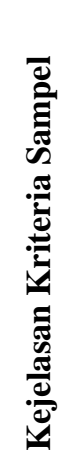 & 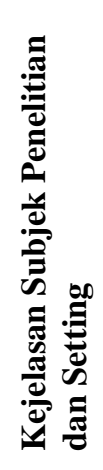 & 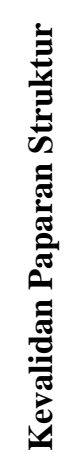 & 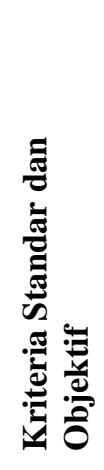 & 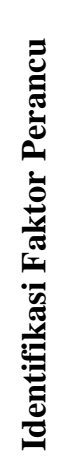 & 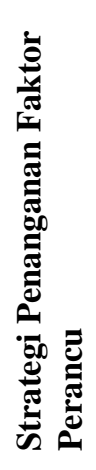 & 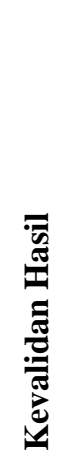 & 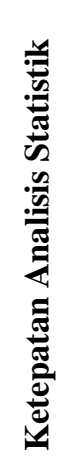 \\
\hline $\begin{array}{l}\text { Singh, I. et al. } \\
(\mathbf{2 0 1 8})^{16}\end{array}$ & + & + & + & + & - & $x$ & + & + \\
\hline $\begin{array}{l}\text { Rusyati, L. M. } \\
\text { et al. }(2019)^{15}\end{array}$ & + & + & + & + & - & $x$ & + & + \\
\hline $\begin{array}{l}\text { Pepineli, A. C. } \\
\text { et al. (2019) }{ }^{12}\end{array}$ & + & + & + & + & - & $x$ & + & + \\
\hline $\begin{array}{c}\text { Partogi, D. et } \\
\text { al. (2018) }{ }^{11}\end{array}$ & + & + & + & + & - & $X$ & + & + \\
\hline
\end{tabular}

Tabel 3. Resiko Bias Studi Artikel menggunakan JBI Critical Appraisal Tools for Analytical Case-Control Studies

\begin{tabular}{|c|c|c|c|c|c|c|c|c|c|c|}
\hline & 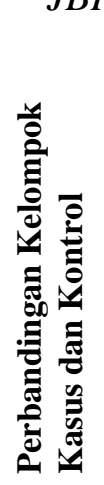 & 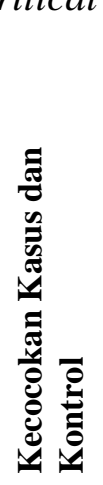 & 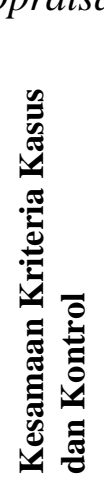 & 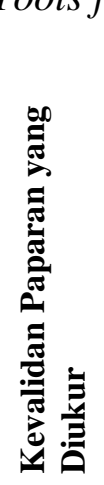 & 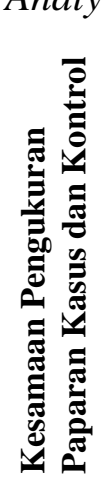 & 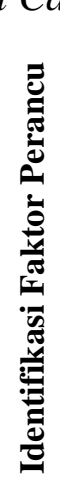 & 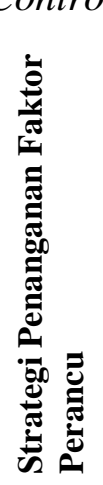 & 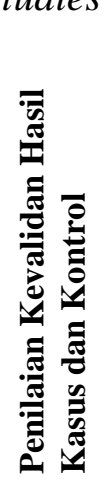 & 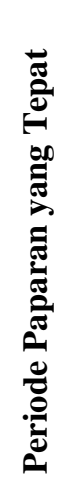 & 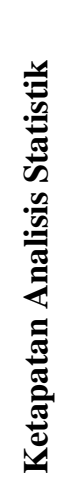 \\
\hline$\underset{(2020)^{14}}{\text { Garg, V. et al. }}$ & + & + & - & + & + & - & $x$ & + & + & + \\
\hline $\begin{array}{l}\text { Rusyati, L. } \\
\text { M. et al. } \\
(2019)^{15}\end{array}$ & + & ? & $?$ & + & + & - & $x$ & - & + & + \\
\hline $\begin{array}{c}\text { Oktaria, S. et } \\
\text { al. }(2018)^{13}\end{array}$ & + & + & - & + & + & + & ? & + & + & + \\
\hline $\begin{array}{l}\text { Oliveira, A. } \\
\text { L. et al. } \\
(2020)^{20}\end{array}$ & ? & ? & - & + & + & - & $x$ & + & + & + \\
\hline
\end{tabular}

\section{A. Hubungan Asupan Vitamin D dengan Indeks Bakteriologi}

Vitamin D berperan dalam menekan perkembangan beberapa penyakit autoimun dan kerusakan jaringan. ${ }^{12}$ Sebuah penelitian menyebutkan bahwa polimofisme Fok I memiliki hubungan dengan kejadian kusta yang lebih konsisten karena Fok I memiliki protein yang bervariasi sehingga lebih efisien dalam memediasi kerja vitamin D. ${ }^{12}$ Secara signifikan polimorfisme Fok I memiliki hubungan dengan kejadian kusta $(\mathrm{p}<0,05) .{ }^{16}$ 
Peran vitamin D pada penyakit kusta telah dibuktikan dengan efek pada vakninasi Bacillus Calmette-Guerin (BCG), faktor pertumbuhan endotel vaskular, prostaglandin, spesies oksigen reaktif, zat antara nitrogen reaktif, metaloproteinase matriks, sindrom antifosfolipid, dan faktor pertumbuhan saraf. ${ }^{14}$ Secara signifikan level serum vitamin D pada pasien penderita kusta lebih rendah dibandingkan dengan individu sehat $(\mathrm{p}<0,05) .{ }^{14,15}$ Pada pasien penderita kusta lepromatous/MB, sistem vitamin D yang mengalami gangguan dapat menyebabkan tingginya nilai indeks bakteriologi [15]. Secara signifikan terdapat hubungan antara level serum vitamin D dengan indeks bakteriologi pasien penderita kusta MB $(\mathrm{r}=-0,954 ; \mathrm{p}<0,001) .{ }^{9}$

Bukti pertama peran vitamin $\mathrm{D}$ pada penyakit kusta muncul di tahun 1940-1950 ketika vitamin D pertama kali dianalisa sebagai pengobatan untuk penyakit kusta. ${ }^{15}$ Pasien penderita kusta lepromatous / MB ditangani dengan cara memberikan kalsiferol sebanyak 15 mgms atau setara dengan 600.000 unit vitamin D2. Pemberian dilakukan 3x/minggu pada minggu ke-1, 2x/minggu selama 3 minggu berikutnya, dan 1 dosis mingguan setelahnya, dan 7 minggu kemudian, semua lesi telah hilang dan hanya menyisakan makula berpigmen. ${ }^{15}$ Pedoman Diet (2015) merekomendasikan asupan harian vitamin D sebesar 600 IU bagi orang dewasa hingga usia 71 tahun dan 800 IU bagi orang dewasa usia 71 tahun ke atas untuk mempertahankan tingkat 25(OH)D yang memadai. ${ }^{1}$ Berbagai sistem biologis pada tubuh akan memberi respons baik ketika kadar 25(OH)D adalah $\geq 30 \mathrm{ng} / \mathrm{ml}$ atau $\geq 0,03$ $\mathrm{mg} / \mathrm{l}$. Secara signifikan asupan vitamin $\mathrm{D}$ berkorelasi dengan level serum 25(OH)D $(\pi=0,29 ; \mathrm{p}<0,01){ }^{17}$

Dari beberapa uraian di atas, secara garis besar menyatakan bahwa defisiensi vitamin $\mathrm{D}$ dapat menyebabkan terganggunya sistem kerja vitamin $\mathrm{D}$ yang berpengaruh pada nilai indeks bakteriologi. Sehingga dapat dikatakan bahwa asupan makanan yang mengandung vitamin $\mathrm{D}$ berperan penting dalam menentukan level serum vitamin $\mathrm{D}$, dimana ketika level serum vitamin D semakin rendah maka nilai indeks bakteriologi akan semakin tinggi.

\section{B. Mekanisme Selenium terhadap Indeks Bakteriologi}

Selenium berperan penting pada sistem kekebalan tubuh dan perlindungan terhadap radikal bebas dengan cara mengaktivasi enzim Glutathione Peroxidase (GPx).7 Kemudian GPx ini mengkatalisis reduksi hydrogen peroxidase dan hydroperoxida organic yang dapat melindungi lemak dari kerusakan oksidatif dengan bereaksi pada komponen seluler atau sistem imun seluler. ${ }^{11,18}$ Pada sistem imun seluler dan humoral, selenium mampu mengatur tingkat interleukin, sehingga mempengaruhi kerentanan terhadap infeksi bakteri. ${ }^{10}$

\section{Hubungan Asupan Selenium dengan Indeks Bakteriologi \\ Selenium berperan sebagai elemen yang} mempengaruhi sistem kekebalan seluler dan humoral, dimana ketika terjadi defisiensi selenium maka dapat menyebabkan respon host yang tidak adekuat terhadap patogen infeksius. ${ }^{11}$ Senyawa selenium yang paling utama diambil sebagai selenomethionine, lalu selenium methylselenocysteine atau $g$ glutamyl-selenium-methylselenocysteine dari sayuran dan sebagai selenocysteine dari daging. ${ }^{10}$ Kemudian senyawa selenium organik terbaru yakni selenoneine, ditemukan pada ikan laut (seperti tuna, mackerel). ${ }^{10}$

Penelitian oleh Oktaria et al. mengidentifikasi korelasi antara faktor demografi, sosial ekonomi, kesehatan dan diet dengan kejadian kusta. $^{13}$ Secara signifikan kerentanan pangan rumah tangga memiliki korelasi dengan peningkatan resiko kejadian kusta $(\mathrm{p}=0,000)$. Hal ini dapat terlihat dari hasil skor kuesioner HFIAS (Household Food Insecurity Access Scale), yang menyatakan bahwa kerentanan pangan pada pasien kusta dua kali lebih tinggi dibandingkan dengan individu sehat $(\mathrm{p}=$ 0,000). Secara signifikan hasil IDDS (Individual Dietary Diversity Score) 
termasuk rendah pada pasien kusta yang mengkonsumsi buah-buahan, sayuran (methylselenocysteine atau g-glutamylselenium methylselenocysteine), telur, kacang- kacangan, dan produk biji-bijian dalam jumlah sedikit. ${ }^{13}$ Hal ini membuktikan bahwa ketika asupan selenium tidak adekuat, maka akan berpengaruh pada pasien penderita kusta.

Status kecukupan selenium biasanya diukur berdasarkan konsentrasi plasma dan serum selenium. ${ }^{19}$ Sebuah penelitian menyatakan bahwa antara asupan selenium dengan level serum selenium saling berhubungan, dimana level serum selenium seseorang mencerminkan asupan selenium yang dikonsumsi. ${ }^{19}$

Secara signifikan terdapat korelasi negatif antara level serum selenium dengan indeks bakteriologi pasien penderita kusta $\mathrm{MB}(\mathrm{r}=-0,499 ; \mathrm{p}<0,005) .{ }^{11}$ Hal ini dapat menjadi acuan bahwa asupan selenium memiliki hubungan dengan indeks bakteriologi, dimana ketika asupan selenium semakin tinggi maka level serum selenium juga semakin tinggi, sehingga indeks bakteriologi akan semakin rendah.

Penelitian ini berdasarkan metode SLR (Systematic Literature Review) dengan jenis penelitian analitik cross sectional dan case control tanpa adanya tindak lanjut atau intervensi diet. Selain itu peneliti masih belum menemukan studi yang secara langsung mengidentifikasi variabel tentang asupan vitamin D maupun selenium pada pasien penderita kusta, sehingga peneliti memasukkan artikel yang berkaitan dengan asupan vitamin $\mathrm{D}$ dan selenium yakni tentang level serum vitamin $\mathrm{D}$ dan selenium. Penelitian ini juga tidak memiliki kriteria inklusi terkait usia pada partisipan, sehingga pada praktiknya penyeleksian partisipan menjadi lebih general atau umum.

Tabel 4. Recommended Dietary Allowances (RDAs) untuk Selenium

\begin{tabular}{|c|c|c|c|c|}
\hline Usia & Laki-laki & Perempuan & Kehamilan & Menyusui \\
\hline Lahir - 6 bulan & $15 \mathrm{mcg} *$ & $15 \mathrm{mcg} *$ & & \\
\hline 7 - 12 bulan & 20 mcg* & $20 \mathrm{mcg} *$ & & \\
\hline 1 - 3 tahun & $20 \mathrm{mcg}$ & $20 \mathrm{mcg}$ & & \\
\hline $4-8$ tahun & $30 \mathrm{mcg}$ & $30 \mathrm{mcg}$ & & \\
\hline 9 - 13 tahun & $40 \mathrm{mcg}$ & $40 \mathrm{mcg}$ & & \\
\hline 14 - 18 tahun & $55 \mathrm{mcg}$ & $55 \mathrm{mcg}$ & $60 \mathrm{mcg}$ & $70 \mathrm{mcg}$ \\
\hline $19-50$ tahun & $55 \mathrm{mcg}$ & $55 \mathrm{mcg}$ & $60 \mathrm{mcg}$ & $70 \mathrm{mcg}$ \\
\hline $51+$ tahun & $55 \mathrm{mcg}$ & $55 \mathrm{mcg}$ & & \\
\hline
\end{tabular}

\section{KESIMPULAN DAN SARAN}

Ketika asupan vitamin D dan selenium adekuat maka akan mempengaruhi level serum vitamin $\mathrm{D}$ dan selenium, sehingga nilai indeks bakteriologi akan menurun. Terdapat korelasi negatif secara signifikan antara level serum vitamin $\mathrm{D}$ dan selenium dengan indeks bakteriologi pasien penderita kusta MB.

Penelitian metode Systematic Literature Review dapat menjadi dasar dalam mengembangkan penelitian lebih lanjut terkait level serum vitamin $\mathrm{D}$ dan selenium dengan penambahan variabel terkait asupan vitamin $\mathrm{D}$ dan selenium yang berhubungan dengan indeks bakteriologi pasien penderita kusta tipe MB.

Secara global jumlah kasus kejadian penyakit kusta setiap tahun masih tergolong tinggi, termasuk Indonesia yang menempati posisi ke-3 tertinggi setelah Brazil. Penelitian metode SLR ini dapat menjadi dasar dalam mengembangkan penelitian lebih lanjut terkait penambahan variabel asupan vitamin $\mathrm{D}$ dan selenium yang berhubungan dengan indeks bakteriologi pasien penderita kusta tipe MB. 


\section{DAFTAR PUSTAKA}

1. Satyareni, D. H. Sistem Pakar Diagnosis Penyakit Infeksi Tropis Dengan Menggunakan Forward Dan Backward Chaining. Teknologi. 2012. vol. 1, no. 2, pp. 61-67. doi: 10.26594/teknologi.v1i2.50.

2. Kemenkes RI. Hapuskan Stigma dan Diskriminasi terhadap Kusta. InfoDatin Pusat Data dan Informasi Kementrian Kesehatan RI. 2018. pp. 1-11.

3. Paschoal. D. Update on Genetics of Leprosy. J. Anc. Dis. Prev. Remedies. 2014. vol. 02, no. 01, pp. 1-6. doi: 10.4172/2329-8731.1000109.

4. Kumar, B., Uprety, S., and Dogra, S. Clinical diagnosis of leprosy. Int. Textb. 2018. Lepr. no. 1, pp. 1-24.

5. OMS. Global leprosy update 2018: moving towards a leprosy free world, Wkly. Epidemiol. 2019. Rec., vol. 35/36, no. 94, pp. 389-412. [Online]. Available:

https://apps.who.int/iris/bitstream/handl e/10665/326775/WER9435-36-enfr.pdf.

6. Kemenkes RI. Profil Kesehatan Indonesia 2018 [Indonesia Health Profile 2018]. 2019.

7. Vázquez, C. M. P, et al. Micronutrientes que influyen en la respuesta immune en la lepra. Nutr. Hosp. 2014. vol. 29, no. 1, pp. 26-36. doi: 10.3305/nh.2014.29.1.6988.

8. Sassi, F., Tamone, C., and D'amelio, P. Vitamin D: Nutrient, hormone, and immunomodulator, Nutrients. 2018. vol. 10, no. 11, pp. 1-14. doi: 10.3390/nu10111656.

9. Rusyati, L. M., Adiguna, M. S., Wiraguna, A. A. G. P., Puspawati, N. M. D., and Sudarsa, P. Correlation of serum Vitamin D receptor level with bacterial index in multibacillary leprosy patients at Sanglah General Hospital, BaliIndonesia. Biomed. Pharmacol. J. 2019. vol. 12, no. 1, pp. 469-472. doi: $10.13005 / \mathrm{bpj} / 1662$.

10. Steinbrenner, H., Al-Quraishy, S., Dkhil, M. A., Wunderlich, F., and Sies, H.,
Dietary selenium in adjuvant therapy of viral and bacterial infections. Adv. Nutr. 2015. vol. 6, no. 1, pp. 73-82. doi: 10.3945/an.114.007575.

11. Partogi, D., Dalimunthe, D. A., and Hazlianda, C. P. A study of selenium in leprosy. Open Access Maced. J. Med. Sci. 2018. vol. 6, no. 3, pp. 485-487. doi: 10.3889/oamjms.2018.136.

12. Pepineli, A. C. et al. Vitamin D Receptor Gene Polymorphisms Are Associated With Leprosy in Southern Brazil. Front. Immunol. 2019. vol. 10, no. October, pp. 1-6. doi: 10.3389/fimmu.2019.02157.

13. Oktaria, S., Hurif, N. S., Naim, W., Thio, H. B., Nijsten, T. E. C. and Richardus, J. H. Dietary diversity and poverty as risk factors for leprosy in Indonesia: A casecontrol study. PLoS Negl. Trop. Dis. 2018. vol. 12, no. 3, pp. 1-15. doi: 10.1371/journal.pntd.0006317.

14. Garg V. et al. Vitamin a, c, d, e and b12 levels in leprosy: A case control study. Indian J. Lepr. 2020. vol. 92, no. 2, pp. 81-88. doi: 10.1016/j.jns.2019.10.1264.

15. Rusyati, L. M. M., Karmila, I. G. A. A. D., and Sudarsa, P. Increased risk of multibacillary leprosy among patient with low plasma vitamin D level. $J$. Glob. Pharma Technol. 2018.vol. 10, no. 5, pp. 29-35.

16. Singh I. et al. VDR polymorphism, gene expression and vitamin $\mathrm{D}$ levels in leprosy patients from North Indian population. PLoS Negl. Trop. Dis. 2018. vol. 12 , no. 11, pp. 1-14. doi: 10.1371/journal.pntd.0006823.

17. Funderburk, L. L., Peterson, M., Shah, N., Morgan, M., and Grandjean, P. Serum vitamin $\mathrm{D}$ and body composition in adults undergoing fitness assessments: A correlation study. PLoS One. 2018. vol. 13, no. 6, pp. 1-10. doi: 10.1371/journal.pone.0197903.

18. Guillin, O. M., Vindry, C., Ohlmann, T., and Chavatte, L. Selenium, selenoproteins and viral infection. 2019. vol. 11 , no. 9 .

19. National Institutes of Health. Recommended Intakes. 2021. pp. 1-35. 
20. Grossi de Oliveira A. L. et al. Hypovitaminosis D and reduced cathelicidin are strongly correlated during the multidrug therapy against leprosy. Microb. Pathog. 2020. vol. 147, p.104373.doi:10.1016/j.micpath.2020.1 04373. 